\title{
Richard Stockton MacNeish (1918-2001)
}

Robert N. Zeitlin

\section{OpenEdition}

\section{Journals}

Electronic version

URL: http://journals.openedition.org/jsa/2217

DOI: 10.4000/jsa.2217

ISSN: 1957-7842

\section{Publisher}

Société des américanistes

\section{Printed version}

Date of publication: 1 January 2001

Number of pages: 393-395

ISSN: 0037-9174

\section{Electronic reference}

Robert N. Zeitlin, «Richard Stockton MacNeish (1918-2001) », Journal de la Société des américanistes [Online], 87 | 2001, Online since 17 November 2005, connection on 15 September 2020. URL : http:// journals.openedition.org/jsa/2217 


\title{
NÉCROLOGIES
}

\author{
Richard Stockton MACNEISH
}

April 29, 1918-January 16, 2001

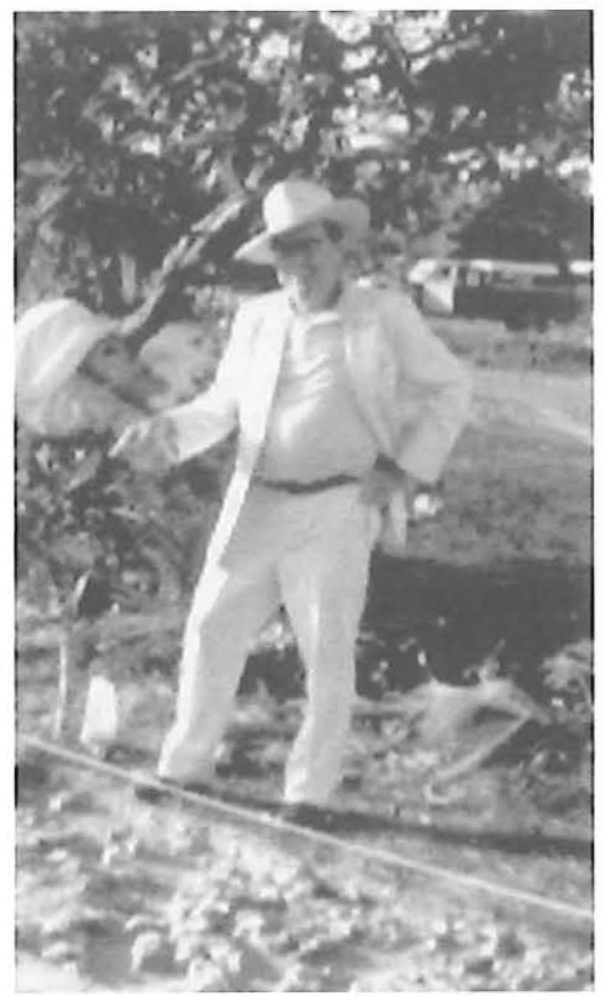

Richard S. « Scotty » MacNeish at the Lowe Ranch archaeological site, Belize, C. A., April 1982 Photograph by Robert N. Zeitlin

On January 16, 2001, archaeology lost one of its most distinguished practitioners and arguably its most colorful character when Richard Stockton MacNeish, affectionately known as "Scotty » to friends and colleagues, succumbed to injuries suffered in an automobile crash in the Mountain Pine Ridge area of Belize. Unwilling, 
despite a failing heart, to surrender his passion for being in the field, he was 82 years old when he lost control of the car he was driving on a visit to some Maya archaeological sites. A raconteur non pareil, his trip to the hospital in Belize City, where he died shortly after arrival, was reportedly spent regaling the British Army patrol who happened upon the accident with his archaeological experiences.

Born in Harlem on April 29, 1918 into a prominent New York family (his mother, the former Elizabeth Stockton, was descended from one of the signers of the Declaration of Independence), he spent his childhood years in the fashionable Westchester County community of Eastchester. His interest in archaeology was initially sparked at the age of twelve by a school project on the Maya, a topic he said he chose because, like his own name, it began with the letter M. From that inauspicious beginning, archaeology grew to be an all-consuming intellectual involvement, matched in his youth only by a love of sports. Describing his teenage years as a time of rebellion against family, suburbia, and the world of business, he reluctantly began his college education at Colgate. After a couple of years there, he transferred to the University of Chicago, where he felt his hunger for archaeology would be better satisfied. At Chicago he was awarded a B.A. in 1940, an M.A. in 1944, and a Ph.D. in 1949.

Upon graduation MacNeish was appointed senior archaeologist at the National Museum of Canada. He then moved on to the newly established Department of Archaeology at the University of Calgary, where he served as chair from 1964 to 1968. For the next fourteen years, he was director of the Robert S. Peabody Museum at Phillips Academy in Andover, Massachusetts, out of which he conducted some of his best-known research. He was outspoken in advocating that archaeology should be treated as an independent scientific discipline, separate from anthropology, as is traditional at most U.S. universities. As such, he was appointed a Research Professor at Boston University's Department of Archaeology from its founding in 1982 until 1986, when he created the Andover Foundation for Archaeological Research (AFAR), whose generous patrons supported his last years of fieldwork.

Above all MacNeish considered himself a « dirt archaeologist. » Unencumbered for most of his career with the constraints of teaching and other academic obligations, he prided himself at having spent over 6,000 days in the field. Beginning in 1936 his archaeological fieldwork took him from New York, Pennsylvania, Arizona, Illinois, Kentucky, and California in the U.S., to Manitoba, the Yukon and the Northwest Territories of Canada, as well as to Mexico, Guatemala, Honduras, Belize, Peru, and China.

Although they did not always agree with his interpretations, those who knew him were awed by his uncanny knack for finding the archaeological needle in a haystack. His most famous discovery was the tiny maize cobs, ancestors to modern corn, excavated from caves in Mexico's Tehuacán Valley. Although recent reanalysis suggests that these early remains may be around 4500 years old, rather than the 7,000 year date he has ascribed to them, they have nevertheless provided a basis for understanding the domestication of this all-important New World staple. As one of the first American archaeologists invited to work in China after the recent warming of cultural relationships with the U.S., he found the remains of rice thought to be 9,000 years old, which would mark the middle Yangtze River region as the locus of its initial domestication. 
For MacNeish, the transition from nomadic hunting and gathering to a settled, agricultural way of life represented a particularly fascinating era in human cultural evolution, and some of his most enduring research efforts were applied to studying how and why it occurred. His large-scale reconnaissance and excavation project in Tehuacán, carried out between 1960 and 1965 and published with his collaborators in an exhaustive five volume edited series, stands as a groundbreaking monument to interdisciplinary archaeological research. Subsequently he attempted to apply the model of agricultural evolution he developed at Tehuacán to highland Peru and lowland Belize, as well as to the birth of rice agriculture in China. At the time of his death he was planning a project in Turkey to study the origins of wheat domestication. Another of MacNeish's longstanding interests involved the question of when the first humans came to inhabit the Americas. He was a firm believer in an early entry into the New World, a conviction that engendered heated controversy among the archaeological orthodoxy which argued for the 12,000 year old Clovis culture as the earliest. Currently the weight of evidence favors MacNeish's position, although his claim that a clay fragment from his 1990 excavation at Pendejo Cave, near Orogrande, New Mexico, is impressed with a 38,000 year old human hand-print has been widely questioned.

MacNeish also stressed the timely dissemination of results, in his case manifested in many articles, reports, lectures, and several books. His presence at professional meetings was ubiquitous. Typically he could be found at the bar; surrounded by colleagues and students, in heated debate over one of his theoretical positions or data interpretations. Although always appearing to relish a good fight in the intellectual ring (while a student at Colgate he also won a Golden Gloves boxing championship), he was not one to harbor a grudge and, typical of his evenhandedness, provided opportunities in his Tehuacán monograph for dissenting interpretations. His stature and contributions to archaeology were recognized in the many professional honors he received, among them the Spinden Medal, Kidder Award, Drexel Medal, Verill Medal, and Cornplanter Medal. He was an elected member of the prestigious National Academy of Sciences.

MacNeish's first marriage to the anthropologist, June Helm, ended in divorce but they remained good friends afterwards. When not in the field, he lived with his wife, Diana (nee Walter) in Andover, Massachusetts. In addition to his wife he is survived by two sons, Roderick and Alexander, both of whom reside in Canada, and a granddaughter. A memorial service celebrating his life was held at the Cochran Chapel at Phillips Academy, Andover on April 28, 2001. Contributions in his memory may be sent to The Richard Stockton MacNeish Fund, c/o the Robert S. Peabody Museum, Phillips Academy, Andover, MA 01810.

Robert N. ZeITLIN

Department of Anthropology, Brandeis University, Waltham MA 